\section{Lembaran Sejarah}

ISSN:

1410-4962
Page

$204-220$

\title{
Doom to Disaster? Industrial Pollution in Sidoarjo 1975-2006
}

\section{RONAL RIDHO'I}

Universitas Negeri Malang

\begin{abstract}
Massive industrialization causes various pollutions (water, air, land and noise). Until early 2000s, facts proved that the environmental condition of Sidoarjo getting worse because of the high level of pollution in this area. This paper aims to explain industrial pollution, regulation of pollution and the debate of pollution cases in Sidoarjo since 1975-2006. Author uses an environmental history approach to analize this phenomenon, and peruses archival sources, newspapers, magazines and interview. This research finds out that industrial pollutions in Sidoarjo still continuously happen until today. Meanwhile, the govenrment regulations were not effectively decrease industrial pollutions because of collusion practice between industrialists and local government, and even with the military personnel particularly during the New Order. This paper proves that the government regulations and law enforcement about the environment were not resolving the pollution problems in Sidoarjo.
\end{abstract}

\footnotetext{
Abstrak

Masifnya industrialisasi di Sidoarjo menyebabkan berbagai macam polusi (air, udara, daratan dan suara). Beberapa fakta membuktikan hingga awal 2000-an kondisi lingkungan di Sidoarjo bertambah buruk karena fenomena polusi yang sering terjadi. Tulisan ini bermaksud untuk memaparkan fenomena polusi industri, peraturan terkait polusi dan perdebatan kasus polusi di Sidoarjo sejak 1975-2006. Fenomena tersebut dikaji dengan perspektif sejarah lingkungan, serta menggunakan sumber koran, majalah maupun arsip pemerintah. Hasil penelitian menunjukkan bahwa polusi industri di Sidoarjo masih terus berlangsung. Peraturan pemerintah belum bisa memberi efek jera bagi pencemar lingkungan karena ada praktek kolusi antara pengusaha dengan pemerintah, bahkan dengan oknum militer pada masa Orde Baru. Tulisan ini membuktikan bahwa regulasi dan penegakan hukum tentang lingkungan masih belum mampu mengendalikan dan menyelesaikan permasalahan polusi di daerah ini.
}

\section{Keywords:} Industry; Pollution; Environment; Sidoarjo

Kata kunci: Industri; Polusi; Lingkungan; Sidoarjo 


\section{Introduction}

Pollution is a phenomenon of industrialization. In the developing country like Indonesia, pollution has been a public phenomenon since 1970s. In the early New Order period, Soeharto focused on economic development by advancing of manufacturing industry, aside from the agricultural sector. Many investors and enterprises built various factories particular industrializing regions in the country. Consequently, since mid 1970s there cases of pollution became significantly widespread. For instance, sugar factory pollution in Semarang, Mas River in Surabaya pollution and Mangaten Kanal River in Sidoarjo. This article focus the pollution in the regency of Sidoarjo, a satellite city of Surabaya. A regency has expanded its manufacturing industry since 1950s and industrialized significantly during the New Order.

Massive industrialization in Sidoarjo creates pollution to the the environment (air, water, land and noise). These include the pollution of the Mas River (1975-1977) by PT. Miwon, ${ }^{1}$ up to the Lapindo mud flow disaster, which being a biggest case in the history of pollution in Sidoarjo. ${ }^{2}$ Local government conducted serious efforts to decrease the pollution, such as enacting Prokasih (Clean River Program), PROPER (factory evaluation program) and Program Langit Biru (Blue Sky Program), yet the program did not reduce the pollution. Kristanto in 2005 found out that the air in West Sidoarjo was polluted by $\mathrm{CO}$ (carbon monoxide) from factories and vehicles smoke. ${ }^{3}$ Meanwhile, BLH (Environmental Agency) Sidoarjo in 2002 noted that $61,25 \%$ water pollution caused by industry. The rest is coming from domestic waste $(27,48 \%)$ and agro-industry waste $(11,27 \%){ }^{4}$

Although the regulations were enacted by the government, industrial pollution still happens recurrently. Well were also polluted by industrial sewage. The question is, what kind of pollution that arose in Sidoarjo and why was does it still happen today Why has government regulations not been able to prevent industrial pollution? According to the argumentations that explained before, historical perspective about the industrial pollution in the past is very interesting to discussed. This study presents the history of industrialization in Sidoarjo and its accompanying environmental degradation.

1) “Surabaya Geger Kepati, Gegernya Air Kena Polusi”,Tempo,24 September 1977, p. 10. See alsoAnton Lucas dan Arief W. Djati, "The Politics of Environmental and Water Pollution in East Java”, in Peter Boomgaard (ed.), A Worl of Water: Rain, Rivers and Seas in Southeast Asian Histories, (Leiden: KITLV Press, 2007), p. 322;

2) Anton Novenanto, "Pemulihan Sosial-Ekologis Lapindo", Kompas, 18 Juni 2013, p. 12 .

3) Candra Kristanto, "The Practice of Environmental Management in Industrial Zone (Case Study: Industrial Zone of Krian By Pass Sidoarjo - Indonesia)”, (Regional and City Planing, UGM Thesis, 2005), p. 48.

4) Ibid., 


\section{Massive Industrialization}

Sidoarjo Regency has a long history of industrialization. In 1830s, the colonial government developed this area as a sugarcane plantation and center for sugar industry because of the fertile land and abundant water supply. ${ }^{5}$ That condition also continued until the late colonial period with the establishment of 13 sugar industries. Sidoarjo had the highest concentration of sugar industry in East Java. ${ }^{6}$ Meanwhile, colonial government focused the other region, especially in the highland, as a central of tea, coffee and also indigo plantation. Such as in Malang, Jember, Lumajang and Banyuwangi. ${ }^{7}$

One of the main characteristics of Sidoarjo is the large number of rivers, including the Porong River, the Mas River and the branch of both. In the colonial period, sugar industries in Sidoarjo dumped their liquid waste in the river. They also released dark and smelly smoke. Yet, during this period there were no regulation to control that pollution, because of a lack of environmental awareness.

To maintain the existence of the sugar industry after the colonial period, the Indonesian Government nationalized Dutch sugar factories. ${ }^{8}$ In the 1950s the government launched a manufacturing industry project, establishing a caustic soda factory (P.N. Soda) in Waru, a metal processing factory (wire and nail) also in in Waru, and a textile factory (PT. Ratatex) in Balongbendo. ${ }^{9}$ All of these facory were located in the riverbanks and near roads.

Industrialization grew rapidly during New Order period until 2000s because many investors, either foreign or local, built factories in Sidoarjo. ${ }^{10}$ They built the factories surrounding rivers and roads. It same with the period before. However, in this period the phenomenon of pollution made the environmental of Sidoarjo is getting worse. This because many chemical industry established in Sidoarjo, ${ }^{11}$ that directly dumped their waste to the environment. ${ }^{12}$ In the next period not only chemical industry, but also there were diverse industry, including significant investment in the petrochemical sector. One of petrochemical company was PT. Lapindo Brantas, whose

5) Karesidenan Surabaya Archive Collection, No. 561, Jakarta: ANRI.

6) Ronal Ridhoi (a), "Limbah Pabrik di Delta Brantas: Industrialisasi dan Permasalahan Lingkungan di Sidoarjo Jawa Timur, 1950-2006”. (Thesis of History Department UGM, 2017).

7) Robert van Niel, Java Under The Cultivation System: Collected Writings, (Leiden: KITLV Press, 1992).

8) Nationalization Act No. 86/1958 about the Nationalization of Indonesian Dutch Company.

9) Howard Dick, Surabaya City of Work: A Socioeconomic History, 1900-2000, (Athens: Ohio University Press, 2002), p. 295-296.

10) Sensus Ekonomi 2006. East Java BPS Archive Collection, p. 11.

11) Such as paper factory (PT. Tjiwi Kimia) and vetsin factory (PT. Sasa).

12) Ronal Ridhoi (a), op.cit., hlm. 91. See also "Pabrik Vetsin Sasa Diresmikan", Kompas, 14 Juni 1969. 
drilling of gas may have resulted in the mudflow disaster that occurred in 2006. The mudflow volcano resulting from that disaster has become the single greatest case of pollution in the history of industrial pollution of the regency.

\section{Environmental Awareness}

Environmental awareness in Indonesia on the idea of pollution emerged since 1970s. That phenomenon was influenced by the awareness of pollution and its discourse in industrialized countries, such as in the United Kingdom, Germany, The US and Japan that emerged since early 1960s. The discourse of pollution in these region was caused by massive industrialization. ${ }^{13}$ In Japan, water pollution by the metal industry caused the Minamata Disease, which killed a lot of people surrounding the Minamata Bay. In Los Angeles, USA, the residents were annoyed by smog coming from motorized vehicle and the manufacturing industry, in particular the heavy metal industry. Smog covered Los Angeles daily during the 1970s. It also damaged agriculture and crops around the city. Related to these pollution problem, Rachel Carson write a book Silent Spring (1962) as a criticism about environmental problem and industrialization in Los Angeles, United State America. ${ }^{14}$

Some pollution problems above trigged the emergence of environmental movement in the world. After Rachel Carson's book, environmental awareness arose in many industrialized countries. This awareness resulted in the rise of the environmental movement, including the rise of organization such as the Friends of the Earth (1969), Greenpeace (1970) and Australian Conservation Foundation (1970). They have a role and also concern on environmental problems, such as pollution, forestry, and also disaster risk management. ${ }^{15}$

In the same decade, environmental movement also emerged in the African and Asian continent. ${ }^{16}$ The rise of manufacturing industry since early 1950s had been a trigger. In Indonesia, the environmental movement has arisen in the form of the WALHI (Wahana Lingkungan Hidup Indonesia) since the 1980s. ${ }^{17}$ The rise WALHI was a response about various environmental problems in Indonesia. Since the President Soeharto conducted REPELITA

13) Otto Soemarwoto, Dampak Lingkungan: Transisi masyarakat Agraris ke Masyarakat Industri, (Bandung: Pusat penelitian Sumber Daya Alam dan Lingkungan Universitas Padjajaran,1985), p. 6-7.

14) Bruce Tranter, “The Environment Movement: Where to From Here?”, in Rob White, Controversies in Environmental Sociology, (New York: Cambridge University Press, 2004), p. 185.

15) Bruce Tranter, Op.cit., p. 188. Look also Freek Colombijn, "Global and Local Perspectives on Indonesia's Environmental Problems and the Role of NGOs”, in Bijdragen tot de Taal-, Land-en Volkenkunde, Vol. 154, No. 2, Globalization, Localization and Indonesia (1998), p. 313-314.

16) John Hannigan, Environmental Sociology, (New York: Routledge, 2006), hlm. 61.

17) WALHI, "Friends of the Earth Indonesia/Wahana Lingkungan Hidup Indonesia”, in www.foei.org, accessed on June 21, 2017. 
(Rencana Pembangunan Lima Tahun) program, many of region in Indonesia began industrializing. Initially, the manufacturing sector grew rapidly without the regulation to pollution, causing environmental problems.

In Sidoarjo, environmental awareness arose recently since late 1980s. It caused by the enactment of the Environmental Act of 1982. Since the enactment of that act, pollution cases began to be notice by the government (local or national). Mass media also focused on pollution. Not only media, but also the population of Sidoarjo's Regency actively reported pollution cases to the Police or local government. It proved by some pollution cases that happened on late 1980s (look at table 1).

\section{From Tofu to Migas; The Experience of Pollution Cases in Sidoarjo}

Pollution has been a public concern for local government in Indonesia. It was because of the emergence of society's awareness about environmental problems, with the role of mass media, environmental movement, and grassroots movement ${ }^{18}$ on the reports of environmental issues and also environmental campaign. Tempo reported the first pollution in Sidoarjo, the pollution of Mas River in 1975 and 1977 that was the impact of factories which located in the riverbanks. The factories dumped their sewage to Mas River without being treated first. As the author explain before, river pollution happened because of massive manufacturing industry in Sidoarjo since the early New Order. ${ }^{19}$ At that time, local and foreign investors started to build their factory in riverbanks to facilitate sewage dumping in the river. ${ }^{20}$

In September 1977, thousands of fishes in the Mas River died. This was caused by the sewage of food additives plant (PT. Miwon) and leather plant (PT. Haka). There are many rivers in Sidoarjo which polluted by sewage plant, such as Mangetan Kanal River (1988), Porong River (1991) and some small rivers in Sidoarjo. ${ }^{21}$ Some factories directly dumped their liquid sewage to the river because at that time there is no regulation about sewage quality standards. Besides that, the environmental control team was formed early by the East Java Governor, Sunandar in August 1975. ${ }^{22}$ Nevertheless, until 2000s, the incidents of river water pollution still continuously happened. PG. Ngadirejo case in Kediri pollutes the Brantas River and liquid contens of

18) Nawiyanto, "Berjuang Menyelamatkan Lingkungan: Gerakan Lingkungan di Jawa Masa Kemerdekaan 1950-2000”, Paramita, Vol. 25, No. 1, January 2015, p. 51.

19) Ronal Ridho'i (b), "Ketika Sungai-Sungai Mulai Tercemar: Polusi Air di Sidoarjo dalam Kajian Historis", in Cut Shafira Salsabila, Bangun Negeriku, Lestari Alamku, (Yogyakarta: Diandra Creative, 2016), p. 257.

20) Anton Lucas and Arief W. Djati, op.cit., p. 322.

21) “Limbah Pabrik Kertas 'P’ Dikeluhkan Penduduk”, Surabaya Post, 18 Juni 1991, p. 3. See also "Pencemar Sungai akan Diadili”, Kompas, 2 November 1988.

22) "Surabaya Geger Kepati”, op.cit., p. 13. 
Lapindo muds that were be dumped to Porong River (look at table 1).

Not only water pollution, but also air pollution occured. It could be seen from the milling process of sugar factory smoke since 1830s. When the early New Order manufacturing investment occurred in Sidoarjo, there were various sources of air pollution. This kind of pollution was inflicted mainly by factory that produced animal feed, packaging food, canning seafood and livestock. Sidoarjo's BLH archives reported the first air pollution was recorded in 1988. This pollution came from the sewage of seafood cannery, PT. Sekar Laut in Sidoarjo District and shrimp paste factory PT. Gilang Jaya in Taman Dstrict. ${ }^{23}$ In the next period, some reports about air polluter was emerged, such as PT. Ujung Timur in Gedangan (1997), animal feed mill PT. Comfeed in Buduran (1998), sound system factory PT. Panggung Elektronik in Waru (2000), ByPass Krian industrial zone (2005), and so on (look at table 1).

Industrialization also caused noise pollution, for instance the noise of factory when producing something, machine vibration in a factory and the other disturbances. Noise pollution happened since the Industrial Revolution in Europe, when scientists made some noise machines that very bothered human hearing. Freek Colombijn classifies noise pollution as soundscape ${ }^{24}$ because it has a relation with the impact of technology modernization in urban area.

Noise pollution actually had already emerged since the establishment of sugar industries in Sidoarjo (1830s). Yet, at that time, the residents around the factory have not presumed that the noise of sugar factory machines was bothering them. Mass media started to reports noise pollution in Sidoarjo in 1990s, that came from the sugar factorie. The pollution occurred in a row with the emergence of society complaint on industrial pollution since the late 1980s. The noise pollution bothered residents' activities, especially during the night. Usually, sugar factory caused noise pollution when producing sugar..$^{25}$

In 2001 Kompas also reported noise pollution of PT. Panggung Elektronik in Waru District. The source of noise came from the sound of production machines and also from dust collector which located 5 metres from public settlement. Afterwards, they complained to Bapedalda (East Java) in order to solve the problems of noise pollution. Bapedalda instructed PT. Panggung Elektronik to repair their silencer tools and also to move their

23) Proper Archive Collection of BLH Sidoarjo: PT. Sekar Laut. Surat No: 660.3/ KPPLH/413.41/1988; Proper Archive Collection of BLH Sidoarjo: PT. Gilang Jaya.

24) Soundscape is the study about sound and noise that inflicted by something or tools in the urban or area. This study analyze music sounds, vehicles, motors and also industrial machines which inflicts a loud sounds and noisy.See Freek Colombijn, "Toooot! Vroooom! The Urban Soundscape in Indonesia”, Journal of Social Issues in Southeast Asia, Vol. 22, No. 2 (October 2007), p. 255-273.

25) “Bising Menjengkelkan, Tenang Didambakan”, Surabaya Post, 7 November 1990, p. 12 . 
Table 1.

Pollution Cases in Sidoarjo and the Pollutant Sources, 1975-2006

\begin{tabular}{|c|c|c|c|c|}
\hline Year & Polluters & Location & \begin{tabular}{|c|}
$\begin{array}{c}\text { The Kinds of Pollution \& } \\
\text { Violation }\end{array}$ \\
\end{tabular} & Action \\
\hline 1975 & PT. Miwon & $\begin{array}{l}\text { Mas River (Taman } \\
\text { District, Sidoarjo \& } \\
\quad \text { Surabaya) }\end{array}$ & $\begin{array}{l}\text { - Water pollution } \\
\text { - Waste dumping in the } \\
\text { river without treatment first }\end{array}$ & $\begin{array}{l}\text { East Java } \\
\text { Government } \\
\text { closed the } \\
\text { factory }\end{array}$ \\
\hline 1977 & $\begin{array}{l}\text { PT. Miwon \& PT. } \\
\text { Haka Surabaya } \\
\text { Leather }\end{array}$ & $\begin{array}{l}\text { Sungai Mas } \\
\text { (Taman District, } \\
\text { Sidoarjo \& } \\
\text { Surabaya) }\end{array}$ & $\begin{array}{l}\text { - Water pollution } \\
\text { - Waste dumping in the } \\
\text { river without treatment first } \\
\text { - Caused the dead of } \\
\text { fishes } \\
\text { - Polluting PDAM water }\end{array}$ & $\begin{array}{l}\text { - East Java } \\
\text { Government } \\
\text { closed the } \\
\text { factory } \\
\text { - Sewer system } \\
\text { closed } \\
\end{array}$ \\
\hline \multirow[b]{2}{*}{1987} & $\begin{array}{l}\text { Leather, iron, } \\
\text { paper, accu, food } \\
\text { additive, sugar } \\
\text { and shrimp } \\
\text { processing } \\
\text { factory } \\
\end{array}$ & $\begin{array}{l}\text { Waru, Buduran, } \\
\text { Gedangan, Tarik, } \\
\text { Krian District }\end{array}$ & $\begin{array}{l}\text { - Water and air pollution } \\
\text { - Those factories dumped } \\
\text { their sewage (liquid and } \\
\text { air) more than maximum } \\
\text { waste quality }\end{array}$ & $\begin{array}{l}\text { The Chief } \\
\text { of Police } \\
\text { in Sidoarjo } \\
\text { rebuked those } \\
\text { factories }\end{array}$ \\
\hline & PT. Tjiwi Kimia & $\begin{array}{l}\text { Mangetan Kanal } \\
\text { River (Tarik and } \\
\text { Krian District) }\end{array}$ & $\begin{array}{l}\text { - Water pollution } \\
\text { - Polluting the Mangetan } \\
\text { Kanal River } \\
\text { - Containing dangerous } \\
\text { chemicals(chlor alcali } \\
\text { andleachate) } \\
\text { - Thousand ducks was } \\
\text { dead }\end{array}$ & $\begin{array}{l}\text { There was no } \\
\text { action from } \\
\text { Sidoarjo's } \\
\text { Government }\end{array}$ \\
\hline 1988 & PT. Sekar Laut & $\begin{array}{l}\text { Pucang Village } \\
\text { \&Kemambang } \\
\text { River }\end{array}$ & $\begin{array}{l}\text { - Water and air pollution } \\
\text { - Stench liquid sewage } \\
\text {-The factory dumped liquid } \\
\text { sewage into Kemambang } \\
\text { River and drainage system } \\
\text { in Pucang Village } \\
\text { - The factory didn't have a } \\
\text { sewage system. } \\
\text { - There was not liquid } \\
\text { sewage checkup in } \\
\text { laboratory }\end{array}$ & $\begin{array}{l}\text { The case was } \\
\text { processed in the } \\
\text { court }\end{array}$ \\
\hline 1988 & $\begin{array}{l}\text { PT. Sidomulyo \& } \\
\text { PT. Sidomakmur }\end{array}$ & $\begin{array}{l}\text { Mas River (Krian } \\
\text { District) }\end{array}$ & \begin{tabular}{|l|} 
- Water pollution \\
- High BOD and COD level \\
- Polluted the Mas River \\
\end{tabular} & $\begin{array}{l}\text { The case was } \\
\text { processed in the } \\
\text { court }\end{array}$ \\
\hline 1989 & PT. Gilang Jaya & $\begin{array}{l}\text { Raya Kletek Road, } \\
\text { Taman District }\end{array}$ & $\begin{array}{l}\text { - Air pollution } \\
\text { - the smell shrimp paste } \\
\text { - The factory didn't have a } \\
\text { sewage system }\end{array}$ & $\begin{array}{l}\text { - warning letter } \\
\text { from residents } \\
\text { - sudden } \\
\text { inspection from } \\
\text { KPPLH Sidoarjo }\end{array}$ \\
\hline 1990 & - & $\begin{array}{l}\text { Sumput River } \\
\text { (Sidoarjo District) }\end{array}$ & $\begin{array}{l}\text { - Water and air pollution } \\
\text { - Polluted Sumput River } \\
\text { - Stench river water } \\
\text { - Liquid Sewage polluted } \\
\text { the ricefield }\end{array}$ & $\begin{array}{l}\text { sudden } \\
\text { inspection from } \\
\text { KPPLH Sidoarjo }\end{array}$ \\
\hline
\end{tabular}




\begin{tabular}{|c|c|c|c|c|}
\hline \multirow[b]{2}{*}{1991} & $\begin{array}{c}\text { PT. Pakerin, PT. } \\
\text { Eureka Aba \& } \\
\text { PT. Jayantara } \\
\text { Sakti }\end{array}$ & Porong River & $\begin{array}{l}\text { - Water pollution } \\
\text { - They dumped the sewage } \\
\text { in Porong River } \\
\text { - They didn't have awater } \\
\text { treatment } \\
\text { - High BOD and COD level }\end{array}$ & $\begin{array}{l}\text { Police } \\
\text { Department } \\
\text { and East Java } \\
\text { Government } \\
\text { gave a } \\
\text { memorandum } \\
\end{array}$ \\
\hline & $\begin{array}{l}\text { Milk Factory \& } \\
\text { cattle breeding }\end{array}$ & $\begin{array}{l}\text { Bulu Sidokare } \\
\text { village, Sidoarjo }\end{array}$ & $\begin{array}{l}\text { - Air pollution } \\
\text { - Cow feces polluting the } \\
\text { Sidokare River }\end{array}$ & $\begin{array}{l}\text { - Residents } \\
\text { denounces } \\
\text { factory to } \\
\text { government } \\
\text { - KPPLH } \\
\text { Sidoarjo team } \\
\text { inspecting the } \\
\text { factory }\end{array}$ \\
\hline 1993 & PT. Tjiwi Kimia & $\begin{array}{l}\text { Mangetan Kanal } \\
\text { River (Tarik and } \\
\text { Krian District) }\end{array}$ & $\begin{array}{l}\text { - Water pollution } \\
\text { - Thousand ducks was } \\
\text { dead } \\
\text { - chlor-alcali and leachate } \\
\text { polluting Mangetan Kanal } \\
\text { River }\end{array}$ & $\begin{array}{l}\text { - denounces } \\
\text { to LBH, } \\
\text { LSM, KPPLH } \\
\text { andSidoarjo } \\
\text { Regent } \\
\text { - meeting and } \\
\text { discussion } \\
\text { with LBH, } \\
\text { breeder factory } \\
\text { delegates } \\
\end{array}$ \\
\hline \multirow[b]{2}{*}{1997} & PT. Ujung Timur & $\begin{array}{l}\text { Gatot Subroto } \\
\text { Road, Gedangan }\end{array}$ & $\begin{array}{l}\text { - Air pollution } \\
\text { - Stench sewage } \\
\text { - Polluting the drainage } \\
\text { system }\end{array}$ & $\begin{array}{l}\text { - Residents } \\
\text { closes the } \\
\text { sewage duct } \\
\text { - Warning letter } \\
\text { from the factory } \\
\end{array}$ \\
\hline & $\begin{array}{l}\text { Animal feed } \\
\text { factory }\end{array}$ & $\begin{array}{c}\text { Raya Kletek Road, } \\
\text { Taman }\end{array}$ & $\begin{array}{l}\text { - Air pollution } \\
\text { - Stench sewage (rotten } \\
\text { fish \& bone) }\end{array}$ & $\begin{array}{l}\text { - Protest, } \\
\text { residents sends } \\
\text { a warning letter } \\
\text { - There was } \\
\text { no action from } \\
\text { KPPLH Sidoarjo } \\
\text { team }\end{array}$ \\
\hline 1998 & $\begin{array}{l}\text { PT. Comfeed } \\
\text { Indonesia }\end{array}$ & Buduran & $\begin{array}{l}\text { - Water and air pollution } \\
\text { - Stench liquid sewage } \\
\text { - Factory drainage system } \\
\text { was corrupted }\end{array}$ & $\begin{array}{l}\text { - Residents } \\
\text { sends a warning } \\
\text { letter to the } \\
\text { factory } \\
\text { - KPPLH } \\
\text { Sidoarjo team } \\
\text { inspecting the } \\
\text { factory } \\
\text { - Repairing the } \\
\text { sewage and } \\
\text { drainage system }\end{array}$ \\
\hline 2000 & $\begin{array}{l}\text { PT. Panggung } \\
\text { Elektronik }\end{array}$ & Waru & Dust and air pollution & $\begin{array}{l}\text { - Residents } \\
\text { sends a letter to } \\
\text { the factory and } \\
\text { DPRD Sidoarjo } \\
\text { - Moving Blower } \\
\text { machine }\end{array}$ \\
\hline
\end{tabular}




\begin{tabular}{|c|c|c|c|c|}
\hline 2001 & $\begin{array}{l}\text { PG. Ngadirejo } \\
\text { Kediri }\end{array}$ & $\begin{array}{l}\text { Mas and Porong } \\
\text { River }\end{array}$ & $\begin{array}{l}\text { - Water pollution } \\
\text { - Polluting Porong and Mas } \\
\text { River } \\
\text { - Stench river water \& } \\
\text { caused itch }\end{array}$ & \begin{tabular}{|l} 
- Sudden \\
inspection \\
from the East \\
Java Police \\
Departement \\
and BLH. \\
- Repairing the \\
molasses shelter
\end{tabular} \\
\hline 2003 & $\begin{array}{l}\text { Pabrik pakan } \\
\text { ikan }\end{array}$ & $\begin{array}{l}\text { Jeruk Legi Village, } \\
\text { Balongbendo }\end{array}$ & $\begin{array}{l}\text { - Air pollution } \\
\text { - Stench sewage }\end{array}$ & $\begin{array}{l}\text { - Residents gave } \\
\text { a warning to the } \\
\text { factory } \\
\text { - There was no } \\
\text { inspection from } \\
\text { BLH Sidoarjo }\end{array}$ \\
\hline 2005 & $\begin{array}{c}\text { Vehicle and } \\
\text { industrial smoke }\end{array}$ & ByPass Krian Road & $\begin{array}{l}\text { - Dust from industrial } \\
\text { pollutant } \\
\text { - Dust from vehicle } \\
\text { pollutant }\end{array}$ & \begin{tabular}{|l} 
- Emission test \\
by DLLAJ \\
- BLH measured \\
the pollutant
\end{tabular} \\
\hline 2006 & $\begin{array}{l}\text { PT. Lapindo } \\
\text { Brantas Inc. }\end{array}$ & $\begin{array}{c}\text { Porong and } \\
\text { Tanggulangin River }\end{array}$ & $\begin{array}{l}\text { - Water and air pollution } \\
\text { - Liquid mud was dumped } \\
\text { into Porong River } \\
\text { - New mud island formed } \\
\text { in the downstream }\end{array}$ & $\begin{array}{l}\text { - They get a } \\
\text { warning BLH } \\
\text { Sidoarjo } \\
\text { - The President, } \\
\text { Susilo Bambang } \\
\text { Yudhoyono } \\
\text { the mudflow } \\
\text { investigation } \\
\text { team }\end{array}$ \\
\hline
\end{tabular}

Sources: BLH Sidoarjo Archive Collection; Tempo, 24 September 1977; Kompas, 10-11-1993, 15-09-1994, 15-08-2001; Surya, 29-07-1991, 24-11-1997; Surabaya Post, 9-05-1989, 22-11-1990, 11-08-2001; Karya Dharma, 19-07-1991; Suara Indonesia, 26-10-1999;interview with Paidjo Yanto, 30-05-2016 \& Nizamuddin, 26-05-2016

dust collector position to the new location that not bothers the residents. ${ }^{26}$

The biggest pollution phenomena in Sidoarjo occurred on May 29, 2006. A warm mudflow were located in the drilling area of PT. Lapindo Brantas caused a complex effect for human and environment in Sidoarjo. ${ }^{27}$ There were many rice fields and fish ponds in Porong submerged by mud and it couldn't cultivated again. The economic activity of Porong residents were jammed because many factories surrounding the center of mudflow had already been stopped. The mudflow with heavy gasses produced a stench smell that affected human respiratory system. The pollution was even worse when the mud water had been streamed into Porong River. It polluted the

26) "Empat Pabrik Diawasi”, Kompas, 18 Januari 2001, p. 19.

27) Anton Novenanto (a), op.cit., p. 12. 
river ecosystems. ${ }^{28}$

Indonesian President, Susilo Bambang Yudhoyono with the Ordinance No. 142007 presumed this incident as a natural disaster, it is not because of human error or company mistake. The state formed BPLS (Sidoarjo Mudflow Countermeasures Agency) and gave compensations to the victims with the APBN..$^{29}$ It make a new discourse that the state take sides to PT. Lapindo Brantas in which the owner of shareholder in this company is Aburizal Bakrie, the Minister of Coordinator and Citizen Welfare of Indonesia (2004-2009). ${ }^{30}$

Therefore, there are two version of mudflow incident in Sidoarjo. First, Porong residents and some media (such as Kompas and Tempo) assume that this mudflow is a company mistake because they forget to use drill casing when drilling Banjar Panji 1 well. So this event called Lapindo mudflow. ${ }^{31}$ Whereas, some geologist assumes that the mudflow caused by the effect of Bantul earthquake (D.I. Yogyakarta) which occurred two days before (May 27, 2006). So, they called this event as Sidoarjo mud disaster. ${ }^{32}$ Lapindo mudflow is one of the negative impact of industrialization in 2000s. Before the mudflow, there were dozens pollution cases caused by industrialization in Sidoarjo (look at table 1).

Lapindo mudflow still continuously happens until today (look at figure 1). Various environmental damage had already occurred, ${ }^{33}$ yet the Regent of Sidoarjo did not really give attention to this problem. The regent, Saiful Ilah conveyed that he will build the mudflow areas as a tourism destination. ${ }^{34}$ Moreover, he gave permission to PT. Lapindo Brantas to drill new wells which located 4 kilometres from the center of lapindo mudflow, exactly in Kalidawir Village, Tanggulangin District. This is because Sidoarjo has an

28) "Lumpur Cemari Tambak", Kompas, 26 Juni 2006, p. 8; "Lumpur Lapindo Beracun”, Surya, 24 Juni 2006, p. 1; “Aktivitas Ekonomi Sebagian Wilayah Lumpuh”, Kompas, 22 Juni 2006, hlm. 8; see also “Timnas Dukung Pembuangan Air Lumpur ke Porong”, inPressRelease, 16 September 2006, (Sidoarjo: Dinas Informasi dan Komunikasi, 2007), p. 151.

29) Anton Novenanto (a), op.cit.p. 12.

30) Anton Novenanto (b), "Melihat Kasus Lapindo sebagai Bencana Sosial", inMasyarakat, Kebudayaan dan Politik, ed. 23, No. 1, January-March 2010, p. 69.

31) "10 Tahun Lumpur Lapindo, Bencana dan Keberuntungan”, Kompas, 14 Juni 2016, p. 22.

32) Anton Novenanto (b), op.cit., p. 63.

33) Such as the emergence of estuary crocodille in upstream of Porong River on May, 2015. This phenomana occurred because of mud water dumping to Porong River, it causing mud cumulation in the downstream and being a new mud island there (Sidoarjo east coast). The habitat of estuary crocodile had been disturbed, and some of them start to looking for a new habitat in upstream of Porong River. See "Ini Dugaan Penyebab Buaya Muncul di Kali Porong” in http://news.detik.com/jawatimur/2928395/ini-dugaan-penyebab-buayamuncul-di-kali-porong, accessed on June 3, 2015. See also "wow puluhan buaya berjemur di kali porong sidoarjo" in http://surabaya.tribunnews.com/2015/05/24/wow-puluhanbuaya-berjemur-di-kali-porong-sidoarjo?page=3, accessed on June 3, 2015.

34) "10 Tahun Lumpur Lapindo, Bencana dan Keberuntungan", Kompas, 14 Juni 2016, p. 22 
overflow natural gas resource which can increase regional income and realize the public welfare. ${ }^{35}$

There is no awareness from local government of Sidoarjo related to lapindo mudflow. It is not purely a natural disaster, but a socio-ecological disaster that should have resolved. ${ }^{36}$ More than 10 years elapsed, PT. Lapindo Brantas has not completely finished the compensation for the victims. ${ }^{37}$ The Lapindo mudflow incident is one of the complex industrial case in Indonesia. This incident shows that industrialization and excessive natural exploitation caused

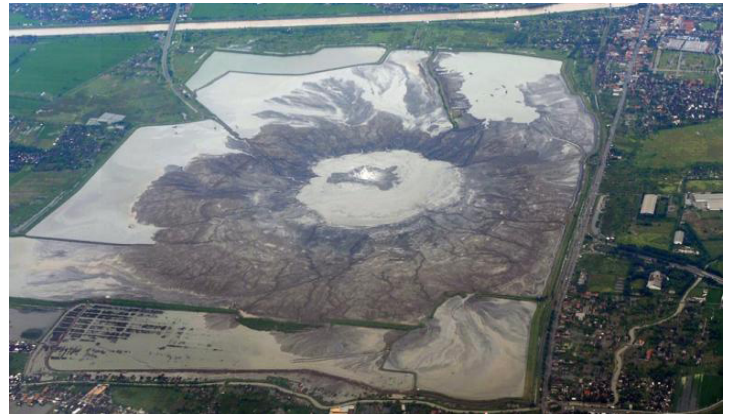

Figure1. Lapindo mudflow photo, 2015. Source: Kompas, 26-04-2016 a tremendous disaster which continuous until today.

\section{Tension and Debate: Pollution Controversy in Sidoarjo}

After the government issued national Environmental Act (UUPLH) in 1982, various pollution cases in Sidoarjo began to be prosecuted. In November 1988 the East Java KPPLH Team ${ }^{38}$ prosecuted Bambang Goenawan (Oei Ling Gwat) the owner of tofu factory and piggeries named PT. Sidomulyo and PT. Sidomakmur because they were pollutes Mas River. ${ }^{39}$ The sewage of both contains high level in BOD (Biochemical Oxygen Demand) ${ }^{40}$ and COD (Chemical Oxygen Demand $)^{41}$, those reach $3.095,4 \mathrm{mg} / 1$ dan $12.293 \mathrm{mg} / 1 .^{42}$ The maximum sewage quality standard which is recommended by East Java Governor is 30 $\mathrm{mg} / \mathrm{l}$ (for BOD) and $80 \mathrm{mg} / \mathrm{l}$ (for COD). ${ }^{43}$ This condition makes a poor quality April 2016.

35) "HUT ke-20 Lapindo, Bupati Minta Warga Setujui Pengeboran”,Tempo, 12

36) Anton Novenanto (b), op.cit.p. 64-65.

37) “Evaluasi, 10 Tahun Kasus Lapindo”,Kompas, 26 April 2016, p. 22.

38) This commission formed by East Java Governor in 1978 based on SK Gubernur Jatim No. 24 Tahun 1978 tetang pembentukan Tim KPPLH (Komisi Pengendalian Pencemaran Lingkungan Hidup) Jawa Timur.

39) “Pencemar Sungai akan Diadili”, Kompas, 2 November 1988. And "Bebas Tak Terbukti Cemari Lingkungan”, Surabaya Post, 9 Mei 1989, p. 1.

40) BOD (Biochemical Oxygen Demand) shows the number of dissolved oxygen which is needed by organism to dissolve waste on water. See Philip Kristanto, Ekologi Industri: Edisi Kedua, (Yogyakarta: Andi, 2013), p. 133.

41) COD (Chemical Oxygen Demand) is chemical reaction to determine the oxygen level that needed by organism when it oxydize organic waste on the water. Philip Kristanto, Ibid., p. 134.

42) “Bebas Tak Terbukti Cemari Lingkungan”, op.cit, p. 1.

43) This level must be obeyed by the company when they dump their waste in all of river in East Java. It can see on the Surat Keputusan Gubernur Jawa Timur No. 43 Tahun 1978 tentang Pengaturan Standar Kualitas Air Buangan Industri di Jawa Timur. 
of Mas River water, because it colour was change and foamy.

The East Java KPPLH Team brought PT. Sidomulyo and PT. Sidomakmur case to the court because they ignored government regulation. Yet, Bambang Goenawan was avowed by the judge because the witness gave contradictory informations. ${ }^{44}$ That was a controversial decision because the result of BTKL (Center of Environmental Health Engineering) laboratory research in Surabaya proved that those sewage plant exceed the sewage quality. This case caused a public concern in the national level and has already been discussed in the third commission of Indonesian Parliament (DPR RI). ${ }^{45}$ Therefore, these water pollution case in Sidoarjo become the first pollution case in Indonesian history which has been brought to the court. ${ }^{46}$

The controversy of these pollution case in Sidoarjo caused by two things. First, the judge is neglectful because of lack attention and knowledge about pollution indicators. The judge assumes that the difference of witness information which has been explained before cannot be a main evidence, so the polluter cannot be prosecuted. ${ }^{47}$ Second, possibility, there is a relation between company (industrialist) with Sidoarjo Regent, so that the polluter get a backing in the tribunal. ${ }^{48}$

The other case that also being vague was paper factory pollution by PT. Tjiwi Kimia. This Eka Tjipta Widjaja's factory located in the Mangetan Kanal River. In early 1990s mass media such as Kompas and Surabaya Post reports that thousands of ducks were died by PT. Tjiwi Kimia water pollution. Since the media reports the pollution case in that river, surrounding societies who get support from LBH (Legal Aid Foundation) Surabaya start to critiques the factory. However, when the delegation of LBH Surabaya and some duck breeders talks with the Regent of Sidoarjo, Edhi Sunyoto, he conclude that Mangetan Kanal River was not polluted. ${ }^{49}$ Even though, investigation of East Java KPPLH proved that the river water had been polluted by chlor alcali and leachate. Both of those chemical liquid is raw and residual materials on paper industry. ${ }^{50}$

44) The judges decision in that court explained that the witness information from BTKL (Center of Environmental Health Engineering) and BPPI (Center of Industrial Research Development) is contradictive. This because there are difference of test result, so the accused Bambang Goenawan could be released. See "Keterangan Saksi Bertentangan, Pencemar Lingkungan Dibebaskan”, Kompas, 10 Mei 1989.

45) “Putusan Kasus Limbah Mengejutkan”, Surabaya Post, 13 Mei 1989, p. 16.

46) “Bebas Tak Terbukti Cemari Lingkungan”, op.cit., p. 1.

47) “Jaksa Kasus Limbah Akan Ajukan Kasasi”, Kompas, 15 Mei 1989, p. 3.

48) Wawancara dengan Endang Budiati (52 tahun). Sidoarjo, 6 Juni 2016. September 1993.

49) "LBH, LSM ingin Bertemu Gubernur Jatim dan Pengusaha”, Kompas, 14

50) Chlor alkali is chemical liquid that use to make a paper. This product is needed by some industry, such as plastic, glasses, fertilizer, paper, pulp industry and so on. Leachate is liquid sewage from midden, containing metal, acid, salt and high level of micro organism, 
Those cases that have been explained is a fact, indeed the handling of pollution in Sidoarjo still vague. If it has analyzed more, Eka Tjipta Widjaja and Bambang Goenawan are the Tionghoa elite. They have an economypolitic relation with Edhy Sanyoto who was a military elite in New Orde era. Eka Tjipta Widjaja, who also the owner of Sinar Mas, has an intense relation with Soeharto because of his cooperation with Soedono Salim (the owner of Salim Group) since 1983. Eka build a network with Salim company is not only a business cooperation, but also he get a military backing from Soeharto. ${ }^{51}$ The relation between military and Tionghoa elite become the most powerful economy-politic network in Indonesia. ${ }^{52}$

The controversy of pollution cases in Sidoarjo continuously happens until 2001. Land pollution case by PT. Maspion I show an awkwardness when the National Police Headquarters doing investigation. Police released a Discontinuation Investigation Letter (SP3) because the evidence of this pollution case is not strong enough. Opposite with that opinion, Bapedal and the Ministry of Environment (KLH) declared that the waste was very hazardous to the human and biota around the company. Although this company was send their waste to the Cileungsi Sewage Treatment West Java, the fact is they still illegally dumped their waste around the company. ${ }^{53}$

From his background of history, Alim Husein (Lim Wen Kwang) family established PT. Maspion since 1971 and then Alim Markus, his son became a leader in this company. Alim Husein family is a Chinese-Indonesian elite who belong to one of the 30 successful conglomerate in New Order era ${ }^{54}$ Aforementioned, Chinese-Indonesian elites often have the backing of military and politicians. The possibility is the relation between Alim Husein family with police elite, so that the National Police Headquarters released an SP3 to stop the pollution cases of PT. Maspion I. Nevertheless, KLH try to reinvestigated this case. ${ }^{55}$ Various tension about industrial pollution cases in Sidoarjo prove that the government and societies shows some critical response to pollution problems. But, pollution cases are always unresolved when the polluters are part of the elite in Indonesia.

so that very dangerous if mixed with clean water. See Helen Njeri Njenga, Industrial Chemistry, (Nairobi: African Virtual University, 2016), p. 76.

51) Richard Borsuk dan Nancy Chng, Liem Sioe Liong's Salim Group: The Business Pillar of Suharto's Indonesia, (ISEAS: Yusof Ishak Institute, 2016), p. 300.

52) Indria Samego (et.al), Bila ABRI Berbisnis, (Bandung: Mizan, 1998), p. 53.

53) "Kementerian LH Kecewa karena Polri Keluarkan SP3 atas Kasus Maspion", Kompas, 22 April 2003, p. 9.

54) Christian Chua, Chinese Big Business in Indonesia: The State of Capital, (New York: Roudtledge, 2008), p. 147.

55) “Kementerian LH Kecewa”, op.cit., hlm. 9. 


\section{Regulations}

Since the Mas River polluted by PT. Miwon in 1975, East Java Governor released the regulation of sewage standard quality (SK Gubernur Jatim No. 43 Tahun 1978). In addition, East Java KPPLH Team also formed in the same year. However, that regulation have not supported enough by Sidoarjo Regency. When the Indonesian President enacted the national Environmental Act in 1982, the pollution issues has been public concern. ${ }^{56}$

The impact of national Environmental Act 1982 is the emerging of various pollution cases in late 1980s. There are many cases that debated by local and central government, such as the pollution case of PT. Tjiwi Kimia (1987), PT. Sekar Laut, PT. Sidomulyo, PT. Sidomakmur (1988), PT. Gilang Jaya (1989) and the other factory. At this period, the Sidoarjo's society had been critical and they also denounced pollution case to the state apparatus.

In 1990s, the government is more stretching and upgrading the quality of regulations. This can seen by the enacting Prokasih (Clean River Program) in 1991, is Proper (factory evaluation program) in 1995 and also Blue Sky Program in 1996. ${ }^{57}$ From Prokasih and Proper local government of Sidoarjo could mapping the polluters. The result, some factory such as PT. Pakerin, PT. Tjiwi Kimia, PT. Comfeed, PT. Ujung Timur, PT. Panggung Elektronik and others had already decreed by government as high potential polluter. However, during 1990-2006 almost every year there were pollution reports (look at table 1). It prove that the government programs (Prokasih, Proper, Blue Sky Program) is not effective when applicated in Sidoarjo. The fact is local government of Sidoarjo just doing the monitoring and also accompaniment to the polluters.

Blue Sky Program (1996) originated from the Ministry of Environment ${ }^{58}$ could not decrease air pollution in Sidoarjo. The monitoring result of air pollution in 1997 indicated that the dust level in Sidoarjo exceed the maximum quality standard of air that regulated by East Java Governor. The dust level reached $0,64 \mathrm{mg} / 1 .{ }^{59}$ It being the high level of air pollution because of three things. First, raw material of industry brought by vehicle contains a lot of dust, especially coal from factory paper and also the raw material of animal feed

56) Undang-Undang Republik Indonesia No. 4 Tahun 1982 tentang Ketentuan-ketentuan Pokok Pengelolaan Lingkungan Hidup.

57) Surat Keputusan Bupati Sidoarjo No. 171 Tahun 1994 tentang Penetapan Sungai yang Merupakan Prioritas dalam Program Kali Bersih (Prokasih) dalam kabupaten Daerah Tingkat II Sidoarjo, hlm. 1-3; Neraca Kependudukan dan Lingkungan Hidup Daerah (NKLD) Kabupaten Sidoarjo 1997, p. 81; Keputusan Menteri Negara Lingkungan Hidup Nomor 15 Tahun 1996 tentang Program Langit Biru. Langit Biru.

58) Keputusan Menteri Negara Lingkungan Hidup Nomor 15 Tahun 1996 tentang Program

59) According to SK Gubernur Jatim No. 188 Tahun 1988 the quality standard of dust pollutant is not more $0,26 \mathrm{mg} / 1$. 
factory. Second, the rest of iron, metal and steel processing at steel industry also produce dust and $\mathrm{CO}$ (carbon monoxide). Third, vehicles that used to carry raw materials. It caused high level of $\mathrm{CO}$ and dust.

Until 2006, some regulations did not reduce the level of industrial pollution in Sidoarjo. Some regulations and government programs which have been described above is not effective. During 1975-2006, pollution cases in Sidoarjo recurrently happened. It caused by the instruction of Sidoarjo Regent that only focused on monitoring and accompaniment, not the effort to prevent. Moreover, the government regulation is not effectively worked because of collution practice between industrialists and local government, even with military personnel during New Order period.

\section{Conclusion}

Industrialization in Sidoarjo caused various pollutions, such as water pollution (river and well), air pollution, land pollution and noise pollution. These phenomena occurred since the mid 1970s and still continuously happens until today. It caused by two things. First, there are politic-economy relations between industrialists, local and central government, so that the completion of pollution cases in Sidoarjo is being vague. Second, regulations and law enforcement from the government were not effectively worked, because the effort of local government only monitoring and accompaniment. There are no preventive actions as well as direct punishment to make a deterrent effect to polluters. Consequently, pollution cases in Sidoarjo recurrently happens until today and it has been a man made disaster like Lapindo mundflow.

\section{References}

\section{Archives and Periodical Publications}

BLH Sidoarjo Proper Archive Collection: CV Gilang Jaya, PT. Java Comfeed Indonesia Tbk, PT. Pakerti Riken Indonesia, PT. Panggung Elektronik, PT. Sekar Laut.

Keputusan Menteri Negara Lingkungan Hidup No. 15 Tahun 1996 tentang Program Langit Biru.

Karesidenan Surabaya Archive Collection No. 561. ANRI: Jakarta.

Nationalization Act No. 86/1958 about the Nationalization of Indonesian Dutch Company.

Neraca Kependudukan dan Lingkungan Hidup Daerah (NKLD) Kabupaten Sidoarjo 1997.

Sensus Ekonomi 2006: Hasil Pendaftaran Perusahaan/Usaha di Jawa Timur. Jakarta: BPS, 2007.

SK Bupati Sidoarjo No. 171 Tahun 1994.

SK Gubernur Jawa Timur No. 24 Tahun 1978.

SK Gubernur Jawa Timur No. 43 Tahun 1978.

SK Gubernur Jawa Timur No. 188 Tahun 1988. 
"Timnas Dukung Pembuangan Air Lumpur ke Porong”, dalam Press-Release, 16 September 2006, (Sidoarjo: Dinas Informasi dan Komunikasi, 2007), hlm. 151.

Undang-Undang Pokok Lingkungan Hidup (UUPLH) No. 4 Tahun 1982.

\section{Newspapers and Magazines}

Kompas: 02-11-1988; 10-05-1989; 15-05-1989; 14-09-1993; 19-08-2000; 18-012001; 14-03-2002; 22-04-2003; 22-06-2006; 26-06-2006; 18-06-2013; 2604-2016; 14-06-2016.

Radar Sidoarjo: 26-06-2003.

Surabaya Post: 9-05-1989; 13-05-1989; 7-11-1990; 30-12-1997; 11-08-2001

Surya: 24-11-1997; 24-06-2006

Tempo, 24-09-1977. p. 10-14.

\section{Thesis, Dissertation and Articles}

Colombijn, Freek (1998). "Global and Local Perspectives on Indonesia's Environmental Problems and the Role of NGOs", in Bijdragen tot de Taal, Land-en Volkenkunde, Vol. 154, No. 2, Globalization, Localization and Indonesia, pp. 305-334.

Colombijn, Freek (2007). "Toooot! Vroooom! The Urban Soundscape in Indonesia”, Journal of Social Issues in Southeast Asia, Vol. 22, No. 2, pp. 255-273.

Kristanto, Candra (2005). "The Practice of Environmental Management in Industrial Zone (Case Study: Industrial Zone of Krian By Pass Sidoarjo Indonesia)". (Regional and City Planing, UGM Thesis).

Nawiyanto (2015). "Berjuang Menyelamatkan Lingkungan: Gerakan Lingkungan di Jawa Masa Kemerdekaan 1950-2000", Paramita, Vol. 25, No. 1, pp. 51-72.

Novenanto, Anton (2010). "Melihat Kasus Lapindo sebagai Bencana Sosial", in Masyarakat, Kebudayaan dan Politik, Th. 23, No. 1, January-March, pp. 63-75.

Ridhoi, Ronal (2017). "Limbah Pabrik di Delta Brantas: Industrialisasi dan Permasalahan Lingkungan di Sidoarjo Jawa Timur, 1950-2006”. (Thesis of History Department UGM).

\section{Books}

Borsuk, Richard \& Chng, Nancy (2016). Liem Sioe Liong's Salim Group: The Business Pillar of Suharto's Indonesia. ISEAS: Yusof Ishak Institute.

Chua, Christian (2008). Chinese Big Business in Indonesia: The State of Capital. New York: Roudtledge.

Dick, Howard W. (2002). Surabaya City of Work: A Socioeconomic Histroy, 1900-2000. Athens: Ohio University Press.

Hannigan, John (2006). Environmental Sociology. New York: Routledge.

Kristanto, Philip (2013). Ekologi Industri: Edisi Kedua. Yogyakarta: Andi.

Lucas, Anton \& Djati, Arief. W. (2007). "The Politics of Environmental and Water Pollution in East Java”. Dalam Peter Boomgaard (ed.), A Worl of Water: Rain, Rivers and Seas in Southeast Asian Histories. Leiden: KITLV Press.

Njenga, Helen Njeri (2016). Industrial Chemistry. Nairobi: African Virtual University. Ridho'i, Ronal (2016). "Ketika Sungai-Sungai Mulai Tercemar: Polusi Air di Sidoarjo dalam Kajian Historis", in Cut Shafira Salsabila, Bangun Negeriku, Lestari Alamku. Yogyakarta: Diandra Creative.

Samego, Indria (et.al) (1998). Bila ABRI Berbisnis. Bandung: Mizan. 
Soemarwoto, Otto (1985). Dampak Lingkungan: Transisi masyarakat Agraris ke Masyarakat Industri. Bandung: Pusat penelitian Sumber Daya Alam dan Lingkungan Universitas Padjajaran.

Tranter, Bruce (2004). “The Environment Movement: Where to From Here?", in Rob White, Controversies in Environmental Sociology. New York: Cambridge University Press.

Van Niel, Robert (1992). Java Under The Cultivation System: Collected Writings. Leiden: KITLV Press.

Wardhana, Wisnu Arya (1995). Dampak Pencemaran Lingkungan. Yogyakarta: Andi Offset.

\section{Websites}

"Ini Dugaan Penyebab Buaya Muncul di Kali Porong" dalam http://news.detik.com/ jawatimur/2928395/ini-dugaan-penyebab-buaya-muncul-di-kali-porong, accessed on June 3, 2015.

"wow puluhan buaya berjemur di kali porong sidoarjo" dalam http://surabaya. tribunnews.com/2015/05/24/wow-puluhan-buaya-berjemur-di-kaliporong-sidoarjo?page $=3$, accessed on June 3, 2015.

WALHI, "Friends of the Earth Indonesia/Wahana Lingkungan Hidup Indonesia", in www.foei.org, accessed on June 21, 2017.

\section{Interviews}

Endang Budiati (BLH Sidoarjo)

Paidjo Yanto (victims)

Nizamuddin (BLH Jawa Timur) 